\title{
Classificação climática de Thornthwaite e Mather na Serra de Baturité e entorno
}

\author{
Thornthwaite and Mather climate classification in Serra do Baturité and \\ surroundings
}

\author{
Ícaro de Paiva Oliveira'; Maria Lúcia Brito da Cruz ${ }^{\text {II }}$
}

\begin{abstract}
RESUMO
Nos estudos da paisagem sob a ótica da geografia física é fundamental entender o contexto climático de uma determinada área, visto que o clima é o agente catalisador da dinâmica natural e influencia na estruturação dos solos e das formações vegetais. Nesse sentido, o artigo em questão tem como objetivo apresentar a classificação climática da Serra de Baturité-CE e seu entorno. Para tanto, foram reunidos dados termopluviométricos a partir de pesquisa em órgãos públicos que trabalham com essa temática. Esses dados foram tabulados, e por meio da metodologia de cálculo escolhida foram classificados 26 postos pluviométricos. Após a classificação os dados foram espacializados e apresentados por meio de mapa temático. Os resultados mostraram que o relevo serrano e seu entorno apresentam variação climática em função da mudança dos níveis altimétricos e consequentemente da temperatura e da umidade do ar. Desse modo, perceber-se que a Serra de Baturité figura como uma paisagem de exceção no contexto dos sertões e que o seu entorno é formado por contextos climáticos de transição e semiáridos.
\end{abstract}

Palavras-chave: Classificação climática; Serra de Baturité; Semiárido

\section{ABSTRACT}

In landscape studies from the perspective of physical geography, it is essential to understand the climatic context of a given area, since climate is the catalyst for natural dynamics and influences the structure of soils and plant formations. In this sense, the article in question aims to present the climate classification of the Serra de Baturité-CE and its surroundings. Therefore, thermopluviometric data were gathered from research in public agencies that work with this theme. These data were tabulated and, through the chosen calculation methodology, 26 rainfall stations were classified. After classification the data were spatialized and presented through thematic map. The results showed that the mountainous relief and its surroundings present climatic variation due to the change of the altimetric levels and consequently of the temperature and the humidity of the air. Thus, it is clear that the Serra de Baturité appears as an exceptional landscape in the context of the hinterlands and that its surroundings are formed by transitional and semi-arid climatic contexts.

Keywords: Climate classification; Baturité Saw; Semiarid

${ }^{\mathrm{I}}$ Doutorando do Programa de Pós-graduação da Universidade Estadual do Ceará. Professor de geografia da Secretaria de Educação Básica do Ceará.. E-mail: icaro256@gmail.com ORCID: http://orcid.org/0000-0002-3284-0069

${ }^{\text {II } D o u t o r a ~ e m ~ G e o g r a f i a ~ p e l a ~ U n i v e r s i d a d e ~ F e d e r a l ~ d e ~ P e r n a m b u c o . ~ D o c e n t e ~ d a ~ U n i v e r s i d a d e ~ E s t a d u a l ~ d o ~ C e a r a ́ ~ d o ~ P r o g r a m a ~ d e ~ P o ́ s-~}$ graduação em Geografia. E-mail: mlbcruz@gmail.com ORCID: http://orcid.org/0000-0002-2202-923X 


\section{INTRODUÇÃO}

Compreender a dinâmica climática é de fundamental importância para os estudos de paisagem, visto que o clima é o catalisador da dinâmica natural. Ele é o responsável por esculpir as formas do relevo por meio da ação do intemperismo e dos processos erosivos. O conhecimento das condições climáticas ajuda a compreender a dinâmica ambiental que, por sua vez, é fundamental para as atividades produtivas humanas, principalmente, em regiões onde o acesso à água ainda é uma questão delicada e conflituosa.

Desse modo, o estudo referente ao contexto climático da Serra de Baturité e seu entorno serve para apresentar didaticamente a relação entre altitude, temperatura e umidade do ar no contexto da semiaridez nordestina, além de demonstrar como a vida, por meio das diferentes formações vegetais, se aclimata a essas mudanças com as adaptações fisiológicas das diferentes espécies.

O Estado do Ceará tem a sua quase totalidade inserida no domínio da semiaridez caracterizada pela irregularidade pluviométrica no tempo e no espaço (ZANELLA, 2007). Há ocorrência de períodos de chuvas abaixo da média com prolongadas secas e outros, quando os valores das precipitações atingem volumes bem acima do normal, podendo ocasionar também sérios danos às diversas comunidades tanto em zonas urbanas como rurais.

Entretanto, mesmo nesse território dominado pela semiaridez, existem espaços em que o contexto climático é totalmente diferente em virtude, principalmente, da influência do relevo com suas cotas altimétricas elevadas. Isso ocorre nas áreas serranas cearenses de Aratanha, Maranguape, Ibiapaba, Meruoca, Uruburetama e na Chapada do Araripe (SOUZA e OLIVEIRA, 2006). Ab'Saber (2002) utilizou a nomenclatura de brejos para se referir a essas áreas, podendo estar nas zonas de cimeira, nas vertentes ou mesmo nos piemontes.

Silva (1987) identificou sete tipos climáticos para o estado do Ceará, com áreas que vão de úmidas a áridas. Em seu trabalho o autor concluiu que em todo o território cearense há déficit hídrico em algum mês do ano, entretanto, isso é acentuado ou atenuado dependendo da altitude e da proximidade do oceano, além da posição de sotavento ou barlavento. 
Muniz et al (2017) destaca a predominância de climas quentes com prevalência de inverno seco. $85 \%$ do estado podem ser classificados com o tipo climático semiárido e em algumas porções encontra-se o tipo climático árido.

Apesar da predominância da semiaridez há, em menor abrangência, uma diferenciação climática quando se aproxima dos altos relevos e do litoral. Nesse caso há uma atenuação semiaridez com volumes pluviométricos maiores (SANTOS e SOARES, 2015).

Oliveira (2018) em estudo sobre o contexto bioclimático da mesma área apresentou dados referentes à temperatura e às tipologias climáticas. $O$ autor concluiu que a metodologia de Thornthwaite e Mather (1955), utilizada neste trabalho, é a que melhor apresenta as variações climáticas da serra e entorno, já que possui a categoria subúmida.

Para serra de Baturité e entorno pode-se afirmar que o relevo aliado à maritimidade e continentalidade tem papel fundamental na estruturação do contexto climático, com cenários distintos, coexistindo em distâncias relativamente pequenas como ocorre em cidades como Guaramiranga e Caridade, separadas por algumas centenas de metros acima do nível do mar e que, por isso, apresentam contextos bioclimáticos totalmente distintos, mesmo estando a poucos quilômetros de distância.

Há também as zonas de transição caracterizadas por indicarem uma quebra momentânea na hegemonia seja da semiaridez. Essa condição de transição interfere diretamente na resposta natural e biológica que é o componente vegetal. Há, naturalmente, mesmo que bastante degradado, um conjunto vegetacional adaptado a esse contexto. Se a vegetação de Caatinga com suas variações fisionômicas e florísticas domina o pediplano e a Floresta Ombrófila ostenta nas áreas elevadas mais úmidas, nas zonas de transição observa-se naturalmente a Floresta Estacional Semidecídua (IBGE, 2002).

Desse modo, o trabalho tem como objetivo apresentar os tipos climáticos presentes na Serra de Baturité-CE e seu entorno. O que proporciona apresentar de modo didático as variações climáticas em função, principalmente, da altitude.

A seguir, está detalhada a metodologia utilizada com base nos autores já citados e os resultados obtidos representados por meio de mapa e tabelas. 


\section{CARACTERIZAÇÃO DA ÁREA DE ESTUDO E PROCEDIMENTOS METODOLÓGICOS}

\subsection{Localização e caracterização da área de estudo}

A área considerada neste estudo diz respeito aos municípios localizados sob a Serra de Baturité e seu entorno (Figura 1). Na porção norte, desde os municípios de Maranguape e Maracanaú até além da porção sul do Maciço, nas cidades de Choró e Itatira. A oeste, desde os municípios que estão imediatamente a sotavento até alguns mais afastados como General Sampaio e Paramoti. A leste, o município de Aracoiaba.

Figura 1 - Mapa de localização.

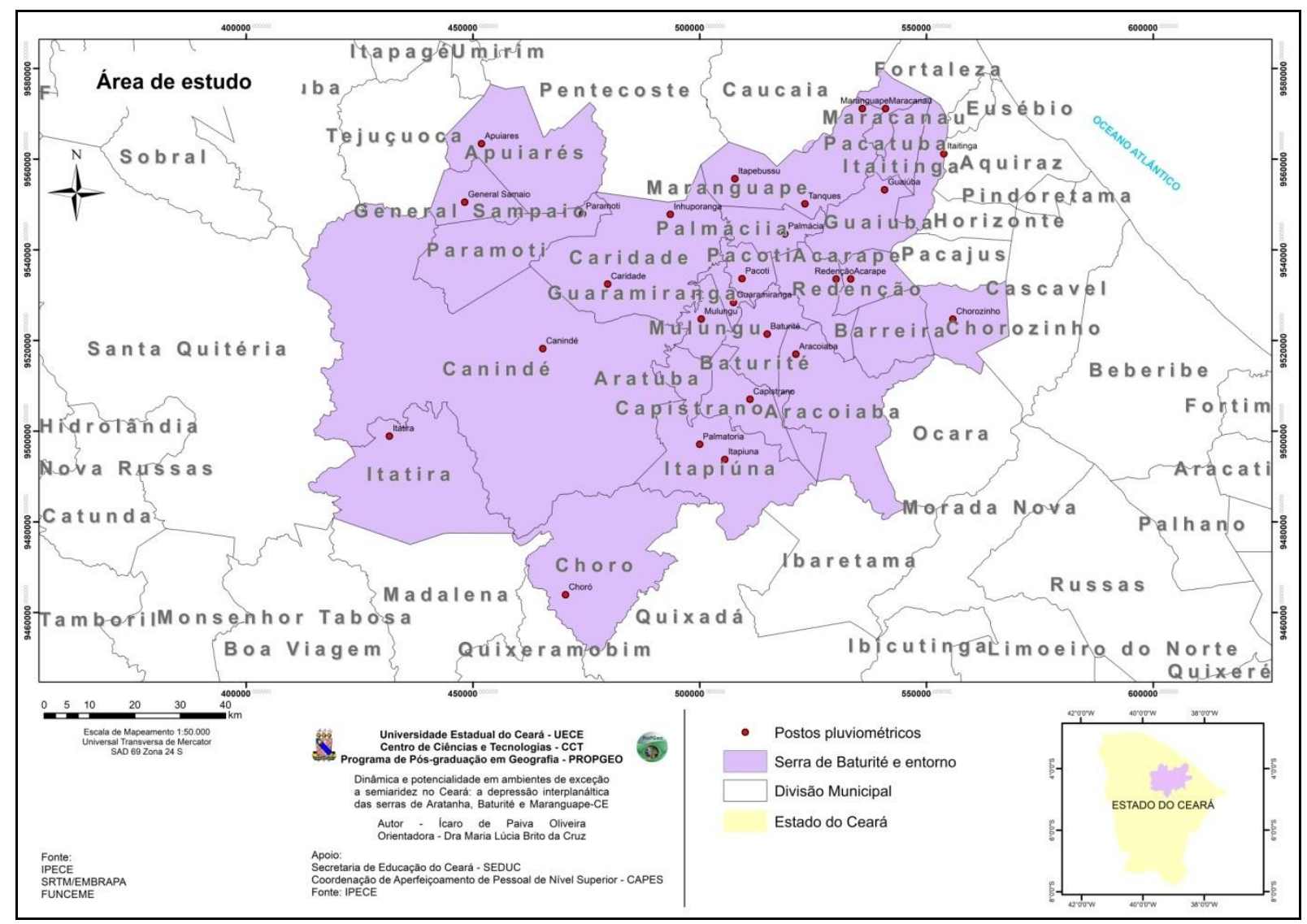

Fonte: Acervo particular dos autores (setembro de 2018)

A maior parte do Ceará está inserida na Região hidrográfica do Atlântico Leste, já a área objeto deste trabalho, inserida totalmente na sub-bacia Litorânea do Ceará com o código 35, com base em Marcuzzo (2017).

Com base em classificação local de COGERH (2007) os postos pluviométricos estão localizados em bacias e sub-bacias apresentadas no Quadro 1. 
Quadro 1 - Postos pluviométricos e bacias hidrográficas em que estão inseridos.

\begin{tabular}{|c|c|}
\hline Posto Pluviométrico & Sub-bacia \\
\hline Acarape & Metropolitana \\
\hline Apuiarés & Curu \\
\hline Aracoiaba & Metropolitana \\
\hline Baturité & Metropolitana \\
\hline Canindé & Curu \\
\hline Capistrano & Metropolitana \\
\hline Caridade & Curu \\
\hline Choró & Metropolitana \\
\hline Chorozinho & Metropolitana \\
\hline General Sampaio & Curu \\
\hline Guaiuba & Metropolitana \\
\hline Guaramiranga & Metropolitana \\
\hline Inhuporanga/Caridade & Curu \\
\hline Itaitinga & Metropolitana \\
\hline Itapebussu & Metropolitana \\
\hline Itapiuna & Metropolitana \\
\hline Itatira & Banabuiú \\
\hline Maracanaú & Metropolitana \\
\hline Maranguape & Metropolitana \\
\hline Mulungu & Metropolitana \\
\hline Pacoti & Metropolitana \\
\hline Palmácia & Metropolitana \\
\hline Palmatória & Metropolitana \\
\hline Paramoti & Curu \\
\hline Redenção & Metropolitana \\
\hline Tanques/Maranguape & Metropolitana \\
\hline
\end{tabular}

Fonte: COGERH (2007)

É importante destacar que foram considerados para o entorno alguns postos de municípios relativamente distantes da serra, em virtude da falta de dados mais próximos com qualidade e sem inconsistências, e por ser necessária uma quantidade razoável de informações para proceder com a interpolação e representação cartográfica dos dados.

A área definida na poligonal apresenta terrenos formados por rochas de embasamento cristalino que sofreram processos de rebaixamento por pediplanação e por aquelas mais resistentes aos processos erosivos que resistiram e hoje formam os maciços de Baturité, Aratanha, Maranguape e Itatira.

A área faz parte Domínio dos escudos e maciços antigos que englobam a maior parte do Estado do Ceará (SOUZA, 1988). São formados, essencialmente, por materiais pré-cambrianos com as formas de relevo exibindo feições que indicam movimentos tectônicos remotos.

As serras supracitadas constituem os Planaltos residuais que estão dispersos sob a depressão sertaneja, contribuindo para uma diversificação paisagística com 
reflexos na variedade de sistemas ambientais. Em geral, possuem relevo dissecado, forjados em litologias metamórficas, recobertos por Argissolos e Neossolos Litólicos que originalmente eram recobertos por Floresta Ombrófila e Floresta Estacional Semidecídua, atualmente, bastante degradadas.

A serra de Baturité possui cotas altimétricas que ultrapassam os $800 \mathrm{~m}$ e sua disposição em relação aos ventos úmidos do litoral proporcionam um ambiente de exceção com a formação de chuvas orográficas na vertente oriental e nas zonas de cimeira. A vertente ocidental, na qual a ação dos ventos oceânicos é restrita, guarda semelhanças com as depressões semiáridas adjacentes (SOUZA, 1988).

Nas áreas úmidas há prevalência do intemperismo químico com coberturas superficiais mais profundas e com maior umidade. Os vales em forma de $V$ indicam a capacidade que a drenagem tem de entalhe em função das condições pluviométricas mais elevadas. Há ocorrências eventuais de planícies alveolares formadas por sedimentos recentes de origem colúvio-aluvionares.

Na porção mais seca o intemperismo químico dá lugar ao desgaste mecânico das rochas e mesmo os Argissolos apresentam-se mais rasos com uma incisão fluvial menos intensa, justificada pela menor capacidade que a drenagem tem de entalhe. Os valores pluviométricos decaem consideravelmente assemelhando-se ao que se verifica nas depressões sertanejas no entorno.

Em termos de vegetação há uma divisão marcante entre os espaços ocupados naturalmente pelas matas úmidas e a porção ocupada por uma mata com características mais próximas de climas secos, denominada por muitos autores de mata seca.

Pereira e Silva (2007) ressaltam que a denominada mata úmida ocupa as porções mais elevadas e úmidas dos altos relevos cearenses e constituem o conjunto vegetacional de maior biodiversidade do Estado, formado por espécies perenes. Há predomínio de espécies arbóreas com destaque para algumas espécies como o mororó, frei Jorge e pau d'arco amarelo e roxo. Atualmente o cultivo desordenado de banana tem contribuído para sua degradação.

Os mesmos autores consideram que a mata seca, vegetação primária das vertentes a sotavento das serras úmidas cearenses, possui caráter semi-caducifólio e uma parte das espécies que a compõem perde suas folhas em função da limitação hídrica. Os mesmos autores consideram que a mata seca, vegetação primária das vertentes a sotavento das serras cearenses possui caráter semi-caducifólio e uma 
parte das espécies que a compõe perde suas folhas durante o período em que não há chuvas. Esse conjunto vegetacional tem tido seu espaço ocupado por espécies de caatinga, menos exigentes, em virtude do avançado processo de degradação ocasionado pelos desmatamentos e queimadas (PEREIRA e SILVA, 2007).

As serras de Aratanha e Maranguape possuem características litológicas semelhantes às de Batutiré com predominância de rochas metamórficas e solos profundos com destaque para os Argissolos recobertos nas áreas, a barlavento, por mata úmida e nas vertentes, a sotavento, por mata seca (SOUZA, 1988).

O município de Itatira assenta-se sob feições que formam 0 conjunto denominado de maciços centrais e ocidentais (SOUZA, 1988; MEIRELES, 2007). Esse conjunto apresenta níveis altimétricos que podem alcançar os 600m com litologias cristalinas pré-cambrianas. Nas vertentes, a barlavento, há predominância de Argissolos recobertos por vegetação de porte arbóreo (Mata seca e Caatinga arbórea). Já nas vertentes, a sotavento, há predominância dos Neossolos Litólicos protegidos por vegetação de porte arbustivo (caatinga arbustiva).

A área pediplanada adjacente aos relevos altos, já mencionados, constitui a unidade paisagística de maior extensão espacial. É formada por rochas cristalinas pré-cambrianas que foram indistintamente erodidas por processos degradacionais. Apresentam drenagem intermitente, sazonal, densa e ramificada em função da baixa permeabilidade do substrato rochoso e das características climáticas. Quanto ao mosaico de solos há ocorrência de Neossolos Litólicos, Luvissolos, Planossolos e Vertissolos, além de Neossolos Flúvicos em áreas de planícies fluviais.

A cobertura vegetal primária é de vegetação de caatinga com suas diferenças fisionômicas e florísticas. É importante destacar que essa vegetação está profundamente alterada em função do processo histórico de degradação, ocasionado pelos ciclos produtivos com destaque para o do algodão e a pecuária extensiva.

Fernandes (2006) afirma que a vegetação de caatinga se constitui na representação sintética dos elementos físicos, com destaque para seu xerofilismo que evidencia uma condição de sobrevivência em um ambiente de clima seco, se comparado com os grandes domínios de paisagem localizados no seu entorno.

Para entender esse contexto ambiental acima descrito, é fundamental compreender como funciona a dinâmica climática regional e local; isso, porém, só é possível a partir de uma análise da circulação atmosférica que por sua vez ajuda a entender os totais pluviométricos. 
Em Brasil (2006) é possível ver que os totais pluviométricos na área estudada apresentam-se em torno de $1200 \mathrm{~mm}$ nas áreas serranas, caem para cerca de $900 \mathrm{~mm}$ a $1000 \mathrm{~mm}$ no entorno a barlavento e para cerca de $700 \mathrm{~mm}$ no entorno a sotavento. Essa chuva começa a cair a partir do mês de janeiro até o mês de maio, entretanto, está mais concentrada entre o primeiro e o quarto mês do ano, sendo consideradas chuvas de verão-outono.

A seguir a Tabela 1 apresenta os totais pluviométricos anuais e altitude de cada posto analisado.

Tabela 1 - Totais pluviométricos anuais para cada posto pluviométrico.

\begin{tabular}{|c|c|c|}
\hline Posto Pluviométrico & Total anual mm & Altitude $\mathrm{m}$ \\
\hline Acarape & 1063,33 & 99 \\
\hline Apuiarés & 764,9 & 77 \\
\hline Aracoiaba & 862,78 & 113 \\
\hline Baturité & 1004,76 & 158 \\
\hline Canindé & 671 & 164 \\
\hline Capistrano & 818,48 & 159 \\
\hline Caridade & 726,6 & 223 \\
\hline Choró & 762,3 & 249 \\
\hline Chorozinho & 793,55 & 67 \\
\hline General Sampaio & 788,5 & 165 \\
\hline Guaiuba & 1072,7 & 66 \\
\hline Guaramiranga & 1534,77 & 860 \\
\hline Inhuporanga/Caridade & 676,3 & 128 \\
\hline Itaitinga & 1099,1 & 68 \\
\hline Itapebussu & 791,71 & 116 \\
\hline Itapiuna & 774,8 & 161 \\
\hline Itatira & 617,9 & 455 \\
\hline Maracanaú & 1193,8 & 45 \\
\hline Maranguape & 1067,1 & 80 \\
\hline Mulungu & 1200,7 & 793 \\
\hline Pacoti & 1387,28 & 737 \\
\hline Palmácia & 1310,38 & 448 \\
\hline Palmatória & 686,11 & 185 \\
\hline Paramoti & 680,4 & 106 \\
\hline Redenção & 1106,65 & 95 \\
\hline Tanques/Maranguape & 928,01 & 123 \\
\hline
\end{tabular}

Fonte: Funceme (2017)

Ferreira e Mello (2005) destacam a atuação de sistemas atmosféricos de pequena, meso e grande escala no NEB. Além das correntes que foram citadas anteriormente, é importante destacar a atuação dos Vórtices Ciclônicos de Altos Níveis - VCAN, Complexos Convectivos de Mesoescala - CCM e as Linhas de Instabilidade - LI.

Santos e Soares (2015) apontam a zona de convergência intertropical e os vórtices ciclônicos de altos níveis como os sistemas atmosféricos de maior destaque 
na produção de chuva no estado durante o verão e outono, período em que se concentram a maior parte da precipitação.

Os VCANs são sistemas que se formam no Oceano Atlântico e adentram o continente pela costa nordestina, entre os meses de novembro e março, com maior frequência nos meses de janeiro fevereiro. São formados por um conjunto de nuvens que circulam em sentido horário e que em sua borda há movimentos de ascendência que permitem a formação de chuvas; já o seu centro é caracterizado pela subsidência inibindo a ascensão do ar pelo aumento da pressão e consequente estabilidade e ausência de precipitação (FERREIRA e MELO, 2005).

Os CCMs são conjuntos de nuvens que se formam a partir de condições favoráveis de relevo, temperatura, pressão, provocando chuvas de curta duração, acompanhadas, geralmente, de rajadas de vento. Já as LI são bandas de nuvens que se formam devido à alta concentração de radiação solar na zona tropical. Na costa do Nordeste brasileiro esse sistema também se forma em decorrência da proximidade da Zona de Convergência Intertropical (FERREIRA e MELO, 2005).

Esse quadro de circulação atmosférica complexo contribui para a distribuição também complexa das precipitações na região, o que leva a constatação de que o semiárido não é homogêneo, uma vez que existem áreas onde elas ocorrem de modo mais intenso e bem distribuído que em outras, dependendo dos sistemas atmosféricos atuantes e da influência dos relevos.

Mendonça e Danni-Oliveira (2007) apresentam dois subtipos climáticos para a região core do que se concebe como semiárido. Os autores os chamam de Clima tropical equatorial com incidência de 7 a 8 meses secos e outro de 9 a 11 meses secos.

Segundo os autores, a marcha estacional na região obedece a três regimes, sendo um Mediterrâneo, um Tropical equatorial e outro Tropical do Brasil central. Naqueles em que domina a semiaridez, a distribuição temporal das chuvas são as seguintes: regime Tropical equatorial - máximo de chuvas no outono e mínimo na primavera; regime Tropical do Brasil central - máximo de chuvas no verão e mínimo no inverno.

Nimer (1989), em uma classificação detalhada das tipologias climáticas do Nordeste e a distribuição de suas chuvas, chama a atenção para a complexidade na distribuição têmporo-espacial da pluviosidade nos sertões nordestinos. Isso se dá em 
decorrência da já citada posição geográfica da região como ponto final de várias correntes e massas perturbadas que por onde passam trazem consigo instabilidades.

É importante salientar que contextos locais como as diferenciações do relevo e a distância em relação ao litoral imprimem modificações nesse quadro climático. 0 relevo por sinal é um fator que contribui para abreviar ou prolongar os períodos de escassez de chuva. 0 que está sintetizado na afirmação abaixo.

Temos visto como é de notável significância o papel da orografia no condicionamento climático da Região Nordeste, principalmente no que afeta a precipitação. Este fator, exercendo tanta importância sobre os totais pluviométricos, acaba por tornar a distribuição do período seco muito complexa nesta região. As saliências locais do relevo abreviam o período seco, enquanto as depressões o prolongam, mesmo tratando-se de topografia cujos acidentes não sejam muito importantes do ponto de vista morfológico (NIMER, 1989, p.341)

\subsection{Procedimentos metodológicos}

Os dados pluviométricos utilizados na pesquisa foram obtidos por meio da Fundação Cearense de Meteorologia e Recursos Hídricos - FUNCEME através do calendário anual de chuvas disponível em seu site na internet. Foram usadas as normais pluviométricas de 26 postos que estão sob a Serra de Baturité e seu entorno. É importante destacar que foram considerados para o entorno alguns postos relativamente distantes da serra em virtude da falta de dados mais próximos e por ser necessária uma quantidade razoável de dados para dar continuidade à interpolação e representação cartográfica dos dados.

Os dados térmicos utilizados foram adquiridos a partir do software CELINA 1.0 que por meio de informações de localização (coordenadas geográficas) e altitude realiza estimativas de temperatura mensal para todo o território do Estado do Ceará. Esses dados, juntamente com os dados de chuva, foram usados no cálculo do balanço hídrico climatológico, utilizando o aplicativo Hidrobio desenvolvido por Camara (1997).

Os procedimentos referentes ao balanço hídrico foram realizados por meio do aplicativo auto-executável Hidrobio (Figura 3) baseado na metodologia de Thorwthwaite e Mather (1955). Precisando apenas da inserção dos valores médios de temperatura e chuvas durante a série histórica.

O aplicativo também fornece informações acerca do período de seca, através do diagrama ombrotérmico de Gaussen, que calcula os períodos de aridez a partir de uma relação entre temperatura e quantidade de chuva. Os períodos de seca estão 
caracterizados, quando o valor médio da temperatura é duas vezes maior que a precipitação.

Figura 3- Tela inicial do aplicativo Hidrobio.

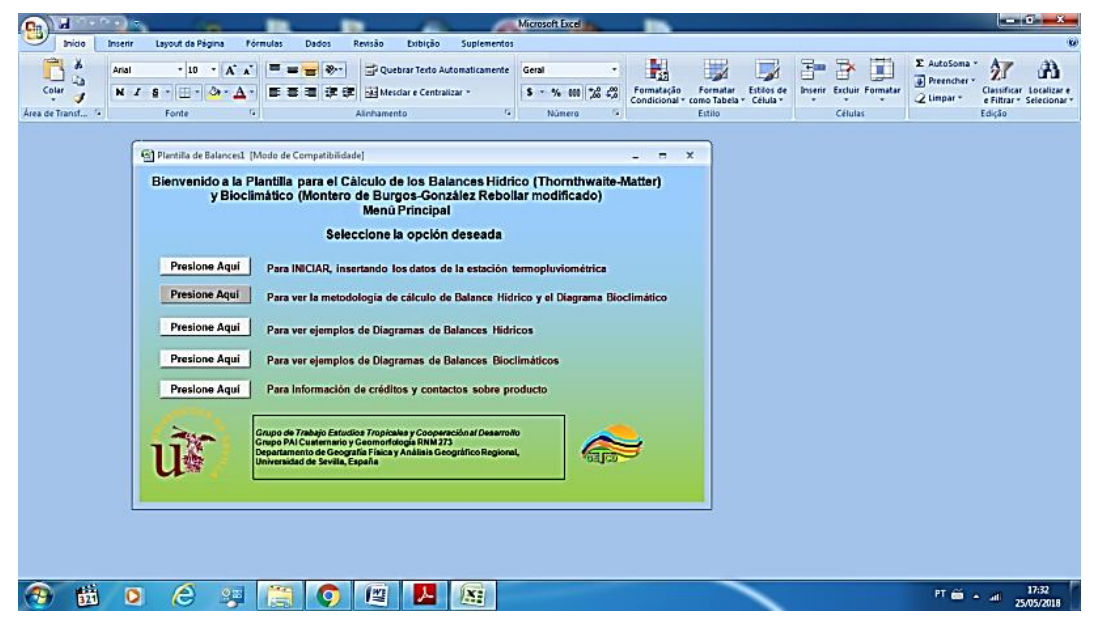

Fonte: Camara (1997)

C. W. Tornthwaite publicou, em 1933, uma classificação climática, posteriormente alterada em 1948, quando propôs um sistema semelhante ao de Köppen, que, de acordo com Mendonça e Danni-Oliveira (2007), assemelha-se ao caráter quantitativo e uso de símbolos e fórmulas, com a diferença que o segundo não empregou valores absolutos de temperatura e umidade como critério para delimitar os tipos climáticos. Nessa proposta foram introduzidos novos aspectos como a eficiência da temperatura e precipitação efetiva.

O sistema climático de Tornthwaite foi revisado em 1955, quando se levou em consideração aspectos relacionados à capacidade de armazenamento de água no solo, segundo a cobertura vegetal e o tipo de solo, chamada pelos autores de retenção de umidade no solo. Ao todo, foram idealizados 120 tipos climáticos, entretanto, nem todos foram utilizados. Sua representação dá-se por meio de 4 símbolos, formados por letras maiúsculas e minúsculas, além de algarismos e apóstrofos.

Para a definição de um tipo climático por meio desse sistema, inicialmente é calculado o índice de umidade que é a relação em porcentagem entre os valores de excedente, déficit e evapotransporação potencial. Ele servirá para identificar o tipo de umidade climática, representado pela primeira letra maiúscula. Para seu cálculo pode ser utilizada a fórmula a seguir.

$\mathrm{Im}=100 \mathrm{~S}-60 \mathrm{D} / \mathrm{ETP}$

$\mathrm{S}$ - excedente de água anual $(\mathrm{mm})$ 
D - déficit de água anual $(\mathrm{mm})$

ETP - evapotranspiração potencial anual $(\mathrm{mm})$

Cabe ressaltar que o valor do índice de umidade efetiva foi a principal informação utilizada na confecção do mapa dos tipos climáticos. Esse processo deuse por meio de interpolação em ambiente SIG.

Em seguida, calcula-se o índice de aridez que expressa deficiência hídrica em percentagem da evapotranspiração potencial. Ele é utilizado para definir a adequação sazonal da umidade. Utiliza-se a seguinte fórmula.

$\mathrm{Ia}=\mathrm{D} / \mathrm{ETP} * 100 \mathrm{em}$ que,

$\mathrm{D}=$ déficit anual $(\mathrm{mm})$

ETP = evapotranspiração potencial anual $(\mathrm{mm})$

A segunda letra da fórmula, (maiúscula ou minúscula, com ou sem algarismo subscrito), apresenta o subtipo climático e diferencia os períodos de excesso e aridez ocorridos durante o ano em função da distribuição intra-anual da pluviosidade (MIRANDA e SANTOS, 2008).

A terceira letra da fórmula representa a eficiência térmica e é o próprio valor da ETP que relaciona a temperatura e fotoperíodo. Usa-se uma letra maiúscula com apóstrofo, com ou sem algarismo posterior.

A quarta letra fornece o subtipo climático indicado a partir da percentagem da evapotranspiração potencial anual para os meses de verão ETP (verão). É representada por uma letra minúscula com apóstrofo e, com ou sem um algarismo subscrito.

A seguir os Quadros 2, 3, 4 e 5 sintetizam as características desse sistema de classificação.

Quadro 2 - Tipos climáticos a partir do índice de umidade.

\begin{tabular}{|c|c|c|}
\hline Símbolo & Tipo de umidade & Índice de umidade \\
\hline A & Superúmido & acima de 100 \\
\hline B4 & Úmido & de 80 a 100 \\
\hline B3 & Úmido & de 60 a 80 \\
\hline B2 & Úmido & de 40 a 60 \\
\hline B1 & Úmido & de 20 a 40 \\
\hline C2 & Subúmido Chuvoso & de 0 a 20 \\
\hline C1 & Subúmido seco & de -33 a 0 \\
\hline D & Semiárido & de $-66,7$ a $-33,3$ \\
\hline E & Árido & de -100 a $-66,7$ \\
\hline
\end{tabular}

Fonte: Mendonça e Danni-Oliveira (2007) 
Quadro 3 - Eficiência térmica e sua concentração no verão.

\begin{tabular}{|c|c|c|}
\hline Símbolo & Tipo & EP $(\mathrm{cm})$ \\
\hline $\mathrm{A}^{\prime}$ & Megatérmico & acima de 114 \\
\hline $\mathrm{B}^{\prime} 4$ & Mesotérmico & de 99,7 a 114 \\
\hline $\mathrm{B}^{\prime} 3$ & Mesotérmico & de 85,5 a 99,7 \\
\hline $\mathrm{B}^{\prime} 2$ & Mesotérmico & de 71,2 a 85,5 \\
\hline $\mathrm{B}^{\prime} 1$ & Mesotérmico & de 57 a 71,2 \\
\hline $\mathrm{C}^{\prime} 2$ & Microtérmico & de 42,7 a 57 \\
\hline $\mathrm{C}^{\prime} 1$ & Microtérmico & de 28,5 a 42,7 \\
\hline $\mathrm{D}^{\prime}$ & Tundra & de 14,2 a 28,5 \\
\hline $\mathrm{E}^{\prime}$ & Geada & abaixo de 14,2 \\
\hline
\end{tabular}

Fonte: Mendonça e Danni-Oliveira (2007)

Quadro 4 - Evapotranspiração de verão.

\begin{tabular}{|c|c|}
\hline Símbolo & Concentração \% \\
\hline a' & abaixo 48 \\
\hline b'4 & de 48 a 51,9 \\
\hline b'3 & de 51,9 a 56,3 \\
\hline b'2 & de 56,3 a 61,6 \\
\hline b' & de 61,6 a 68 \\
\hline c'2 & de 68 a 76,3 \\
\hline c'1 & de 76,3 a 88 \\
\hline d' & acima de 88 \\
\hline
\end{tabular}

Fonte: Mendonça e Danni-Oliveira (2007)

Quadro 5 - Adequação sazonal de umidade.

\begin{tabular}{|c|c|c|}
\hline \multicolumn{2}{|c|}{ Climas úmidos A, B, C2 } & Índice de aridez \\
\hline r & Pouco ou nenhum déficit hídrico & $0-10$ \\
\hline s & Déficit moderado de verão & $10-20$ \\
\hline w & Déficit moderado de inverno & $10-20$ \\
\hline s2 & Grande déficit de verão & Acima de 20 \\
\hline w2 & Grande déficit de inverno & Acima de 20 \\
\hline & Climas Secos C, D, E & Índice de Umidade \\
\hline d & Pequeno ou nenhum excedente de água & $0-16,7$ \\
\hline s & Excedente moderado de inverno & $16,7-33,3$ \\
\hline w & Excedente moderado de verão & $16,7-33,3$ \\
\hline s2 & Grande excedente de inverno & Acima de 33,3 \\
\hline w2 & Grande excedente de verão & Acima de 33,3 \\
\hline
\end{tabular}

Fonte: Mendonça e Danni-Oliveira (2007)

Mesmo existindo outros sistemas de classificação mais utilizados como o de Köppen, para este trabalho preferiu-se o sistema de Thorntwaite e Mather, em 
virtude da categoria climática subúmida não estar contemplada no primeiro sistema. Isso, para o recorte espacial utilizado, poderia comprometer a representação de seu contexto climático homogeneizando condições climáticas distintas. Existe, entretanto, aplicação exitosa, utilizando a segunda metodologia para a classificação climática no Estado do Ceará, como a encontrada em Silva (1987) que serviu de referência para esta pesquisa.

\section{RESULTADOS}

Os resultados mostraram que os tipos climáticos observados no recorte espacial estudado foram do tipo semiárido, subúmido seco, subúmido chuvoso e úmido, havendo predominância do tipo climático subúmido seco. Já o semiárido ocorreu nas áreas a sotavento da Serra de Baturité; o subúmido chuvoso, nas altitudes intermediárias do alto relevo e nas zonas de cimeira a predominância é do tipo úmido.

Nos postos em que foi observado o tipo climático úmido os totais pluviométricos se aproximam dos $1500 \mathrm{~mm}$, como em Guaramiranga no alto da serra, bem diferente do que ocorre em áreas de baixa altitude a sotavento com ocorrência do tipo semiárido como em Inhuporanaga com cerca de $670 \mathrm{~mm}$. Em Maranguape e Tanques, também localizados no pediplano a barlavento, os totais pluviométricos se aproximam dos $1000 \mathrm{~mm}$ e o tipo climático resultante é o subúmido.

A classificação para cada posto está representada a seguir (Quadro 6) e no mapa abaixo (Figura 3).

Quadro 6 - Postos pluviométricos e suas classificações climáticas.

\begin{tabular}{|c|c|c|c|c|c|c|}
\hline Posto & ETP & $\begin{array}{c}\text { ETP verão } \\
\%\end{array}$ & $\begin{array}{c}\text { Índice de } \\
\text { umidade } \\
\text { efetiva }\end{array}$ & $\begin{array}{c}\text { Índice de } \\
\text { aridez/ } \\
\text { umidade }\end{array}$ & Tipo climático & Nomenclatura \\
\hline Acarape & 1670 & 35,24 & $-19,15$ & 2,7 & C1dA'a' & Subúmido seco \\
\hline Apuiarés & 1474,62 & 49,84 & $-31,56$ & 0 & C1d''b'4 & Subúmido seco \\
\hline Aracoiaba & 1618,09 & 35,09 & -28 & 0 & C1dA'a' & Subúmido seco \\
\hline Baturité & 1626,75 & 35,59 & $-22,99$ & 0 & C1dA'a' & Subúmido seco \\
\hline Canindé & 1620,46 & 34,69 & $-35,14$ & 0 & DdA'a' & Semiárido \\
\hline Capistrano & 1623,85 & 34,97 & $-29,75$ & 0 & C1dA'a' & Subúmido seco \\
\hline Caridade & 1632,07 & 35,35 & $-34,94$ & 0 & DdA'a' & Semiárido \\
\hline Choró & 1187,23 & 46,5 & $-30,74$ & 0 & DdA'a' & Semiárido \\
\hline Chorozinho & 1714,05 & 35,38 & $-31,81$ & 0,99 & C1dA'a' & Subúmido seco \\
\hline
\end{tabular}




\begin{tabular}{|c|c|c|c|c|c|c|}
\hline $\begin{array}{c}\text { General } \\
\text { Sampaio }\end{array}$ & 1485,5 & 31,28 & $-29,08$ & 4,6 & C1dA'a' & Subúmido seco \\
\hline Guaiuba & 1692,99 & 35,91 & $-20,09$ & 3,46 & C1dA'a' & Subúmido seco \\
\hline $\begin{array}{c}\text { Guaramirang } \\
\text { a }\end{array}$ & 934,55 & 35,4 & 65,99 & 8,1 & B3rB'3a' & Úmido \\
\hline Inhuporanga & 1632,93 & 35,44 & $-35,18$ & 0 & DdA'a' & Semiárido \\
\hline Itaitinga & 1653,3 & 35,6 & $-20,67$ & 9,63 & C1dA'a' & Subúmido seco \\
\hline Itapebussu & 1644,64 & 35,53 & $-29,42$ & 1,05 & C1dA'a' & Subúmido seco \\
\hline Itapiuna & 1637,98 & 34,89 & $-31,85$ & 10,64 & C1dA'a' & Subúmido seco \\
\hline Itatira & 875,75 & 34,53 & $-43,74$ & 0 & DdB'3a' & Semiárido \\
\hline Maracanaú & 1685,31 & 36,45 & $-19,78$ & 7,37 & C1dA'a' & Subúmido seco \\
\hline Maranguape & 1582,1 & 35,89 & $-21,04$ & 6,39 & C1dA'a' & Subúmido seco \\
\hline Mulungu & 973,77 & 35,31 & 26,77 & 19,83 & B1wB'3a' & Úmido \\
\hline Pacoti & 974,91 & 35,35 & 46,2 & 6,45 & B2rB'3a' & Úmido \\
\hline Palmácia & 1239,58 & 35,21 & 14,64 & 17,75 & C2wA'a' & Subúmido \\
chuvoso \\
\hline Palmatória & 1598,84 & 34,84 & $-33,9$ & 0 & DdA'a' & Semiárido \\
\hline Paramoti & 1664,69 & 34,76 & $-36,69$ & 0 & DdA'a' & Semiárido \\
\hline Redenção & 1675,33 & 35,12 & $-22,31$ & 3,24 & C1dA'a' & Subúmido seco \\
\hline Tanques & 1575,92 & 35,69 & $-24,4$ & 0 & C1dA'a' & Subúmido seco \\
\hline
\end{tabular}

Fonte: Organização dos autores

Figura 3 - Mapa com os tipos climáticos para a Serra de Baturité e entorno.

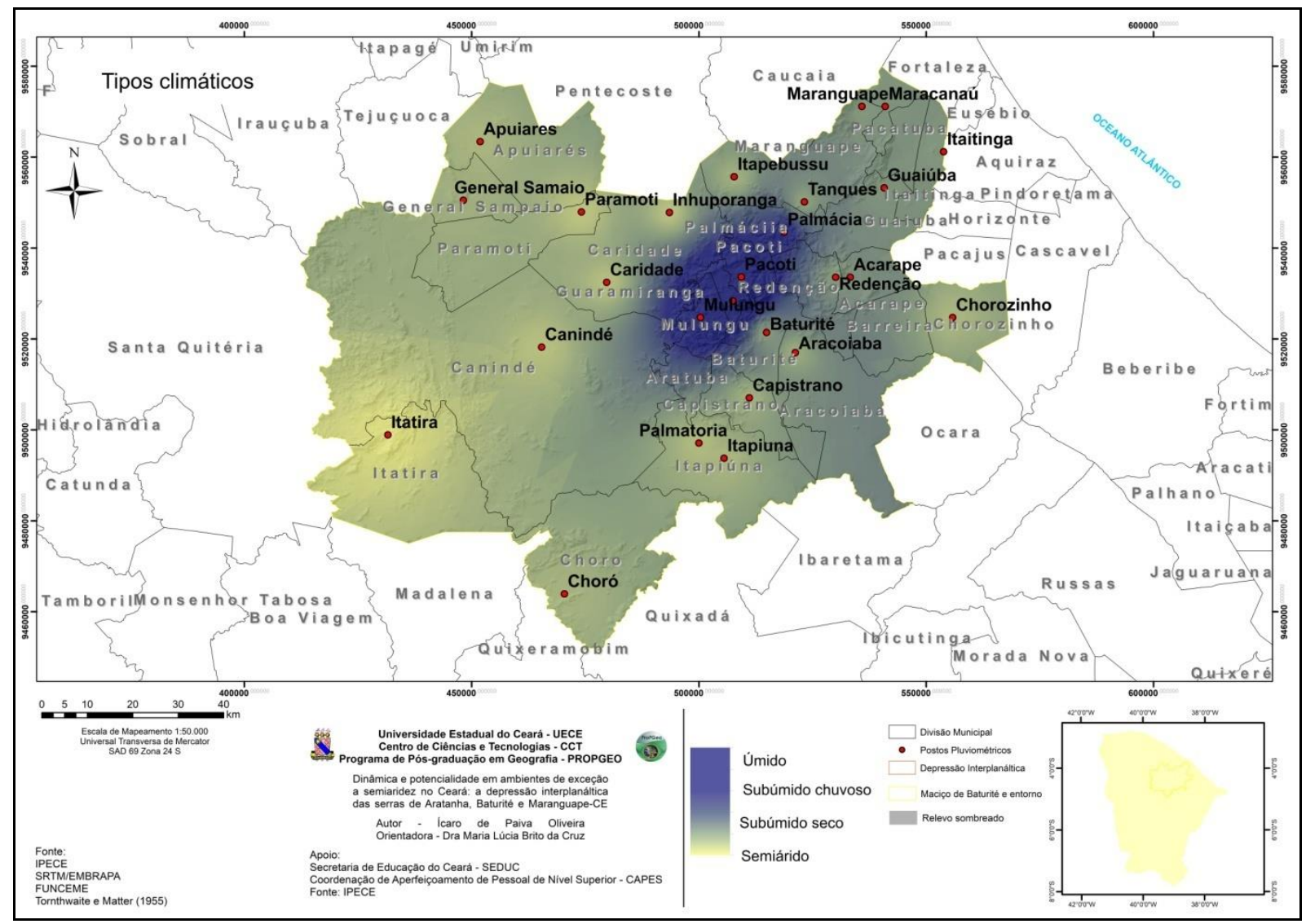

Fonte: Acervo particular dos autores (setembro de 2018) 
O mapa indica uma predominância de climas mais úmidos à medida que aumentam as cotas altimétricas da serra de Baturité. Entretanto o mesmo não ocorre para o posto de Itatira sob uma serra considerada seca. Nessa porção, o fator altitude não impede que a continentalidade influencie na baixa pluviometria. Nas áreas pediplanadas a maior influência da semiaridez pode ser sentida nas áreas a sotavento do alto relevo.

Quanto ao balanço hídrico climatológico pode-se perceber que os períodos de déficit hídrico são maiores nas zonas sob domínio do clima semiárido e vai diminuindo nas zonas de clima subúmido seco, até alcançar os menores valores nas tipologias subúmido chuvoso e úmido. A seguir, estão os gráficos de balanço hídrico de alguns postos escolhidos como representantes de cada tipologia climática. Estão também representados os diagramas ombrotérmicos de Gaussen, indicando os períodos de seca a partir dos dados de termopluviométricos (Figuras 4, 5, 6, 7, 8, 9, 10 e 11). Não é possível apresentar os gráficos de todos os postos em função da estrutura e do que se pretende com um artigo científico.

Figura 4 - Gráfico do balanço hídrico para o posto de Acarape-CE.

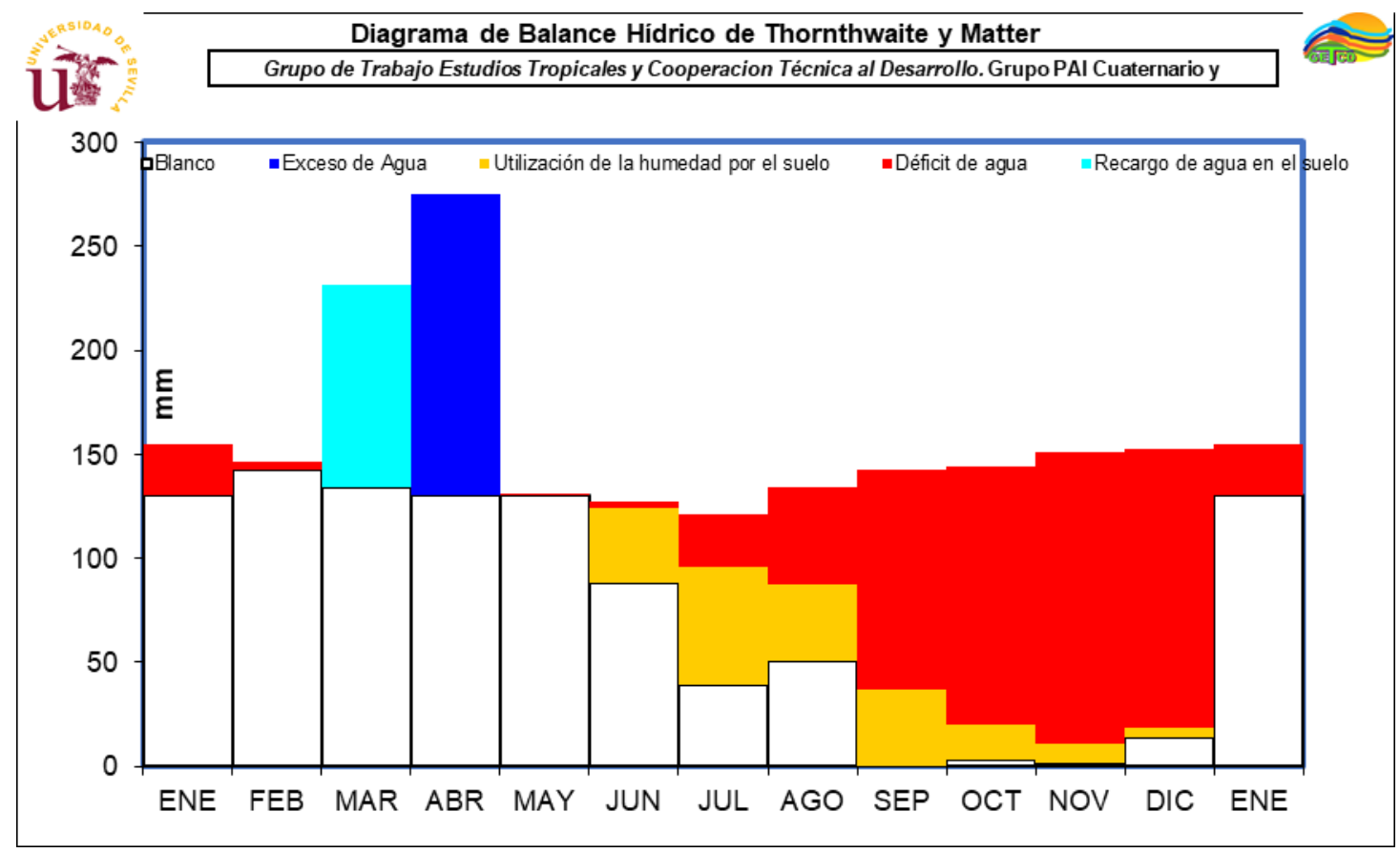

Fonte: Acervo particular dos autores (setembro de 2018) 
Figura 5 - Diagrama ombrotérmico para o posto de Acarape-CE.

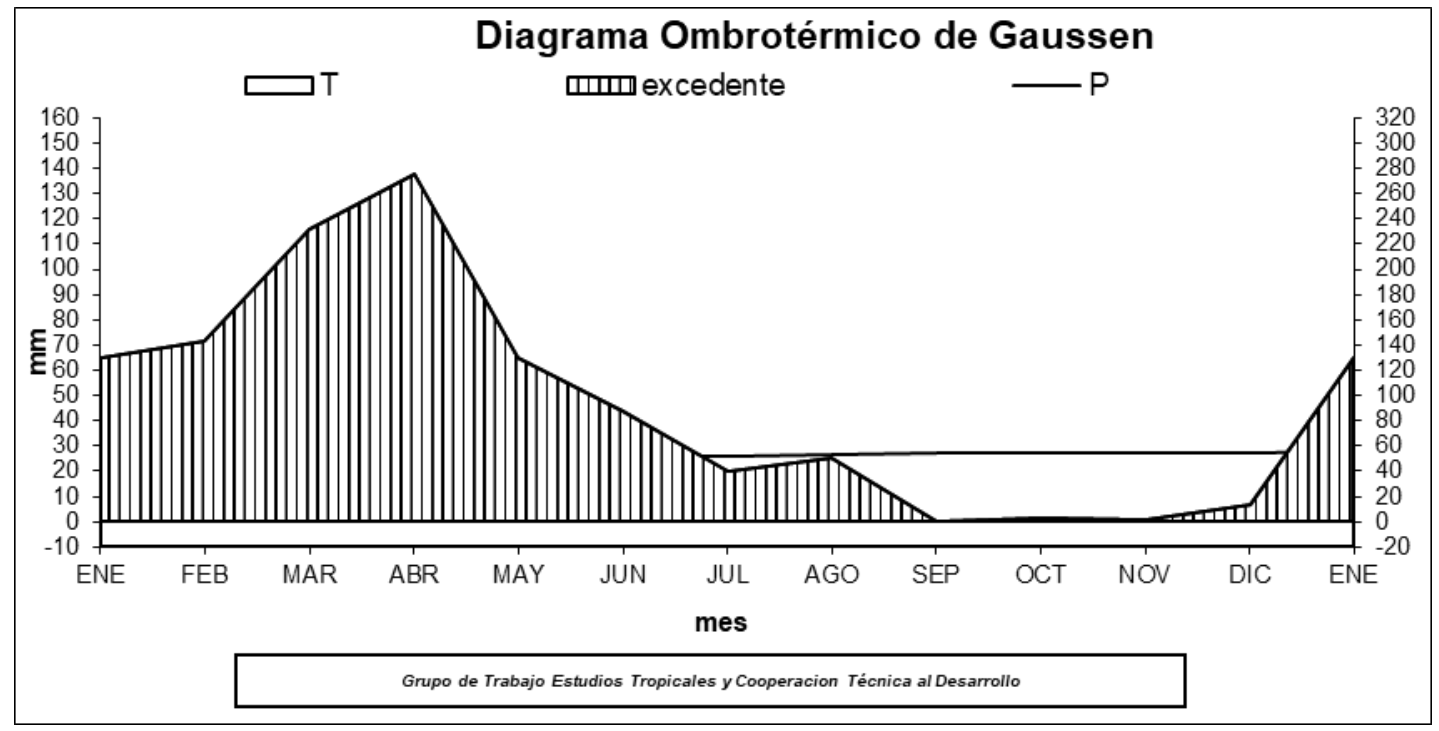

Fonte: Acervo particular dos autores (setembro de 2018)

Figura 6 - Balanço hídrico climatológico para o posto de Caridade-CE.

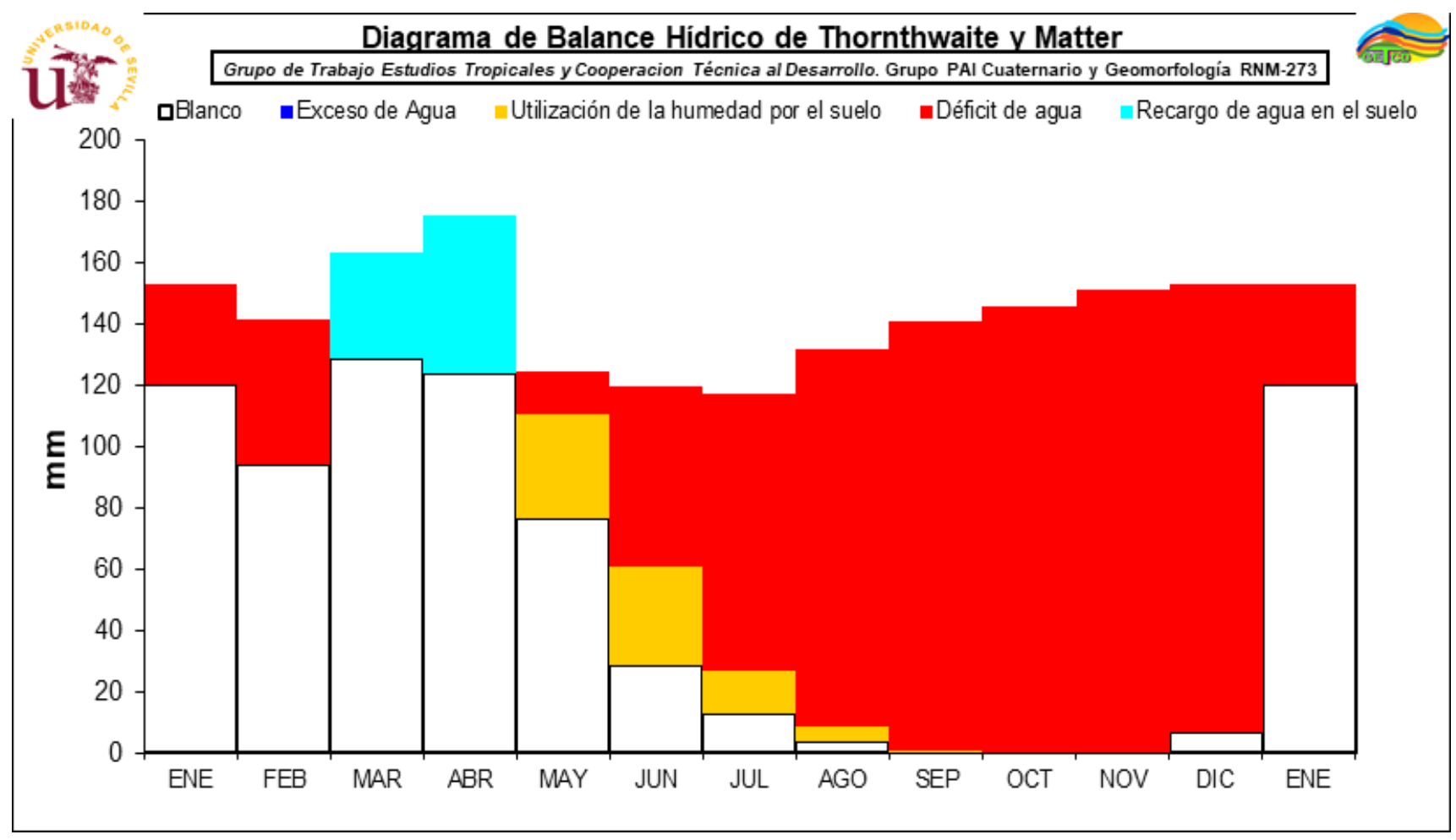

Fonte: Acervo particular dos autores (setembro de 2018) 
Figura 7 - Diagrama ombrotérmico para o posto de Caridade-CE.

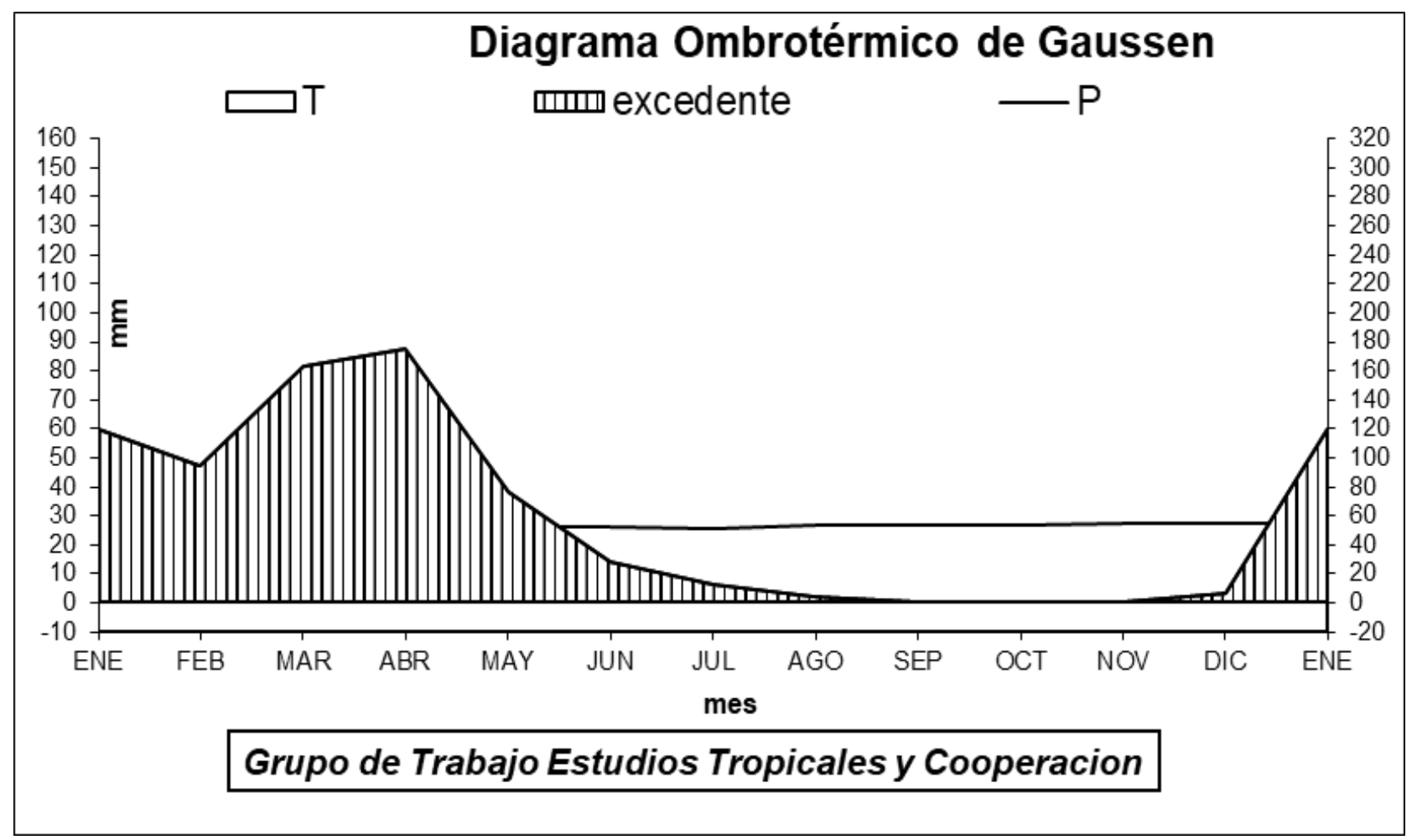

Fonte: Acervo particular dos autores (setembro de 2018)

Figura 8 - Balanço hídrico climatológico para o posto de Palmácia-CE.

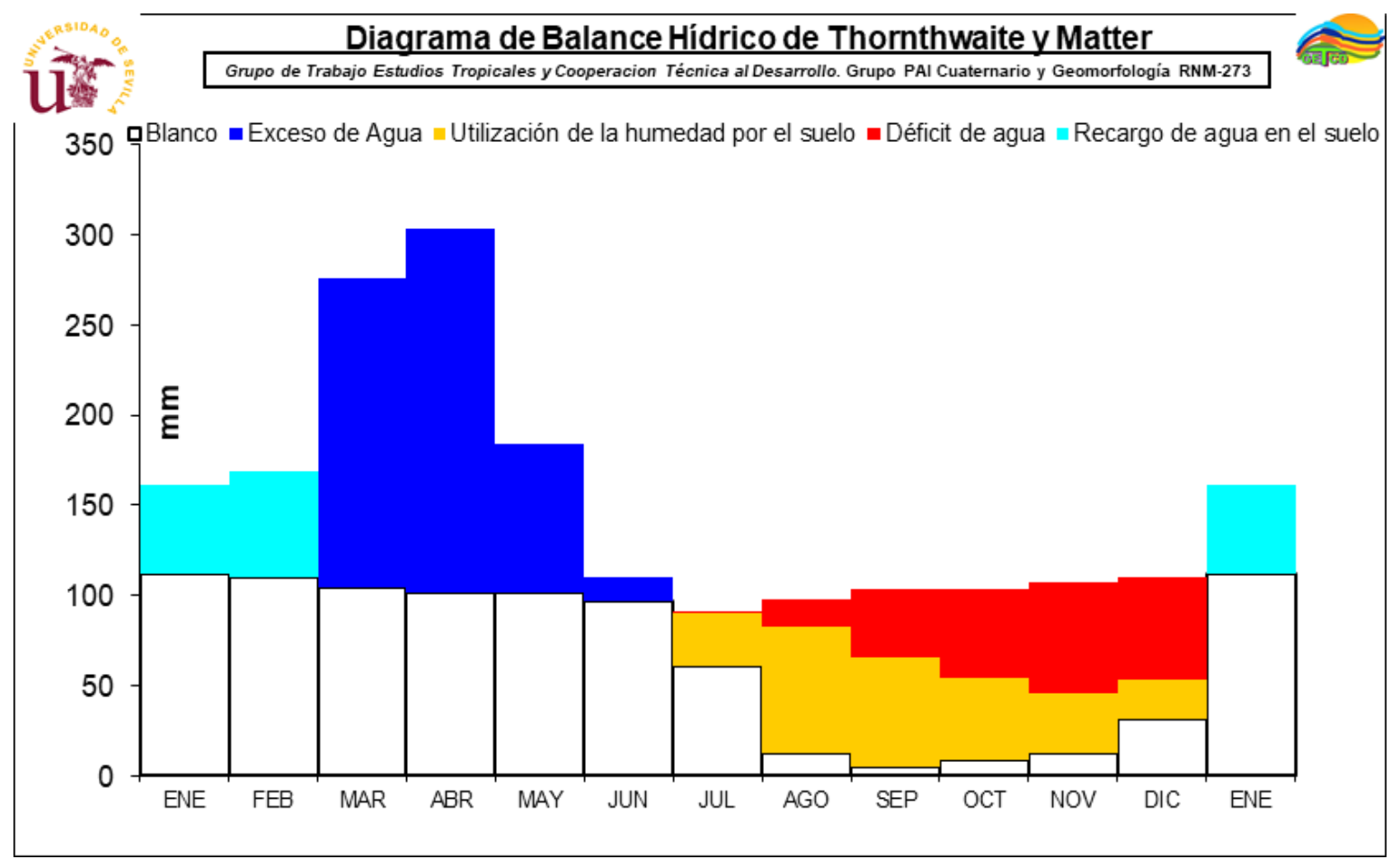

Fonte: Acervo particular dos autores (setembro de 2018) 
Figura 9 - Diagrama ombrotérmico para o posto de Palmácia-CE.

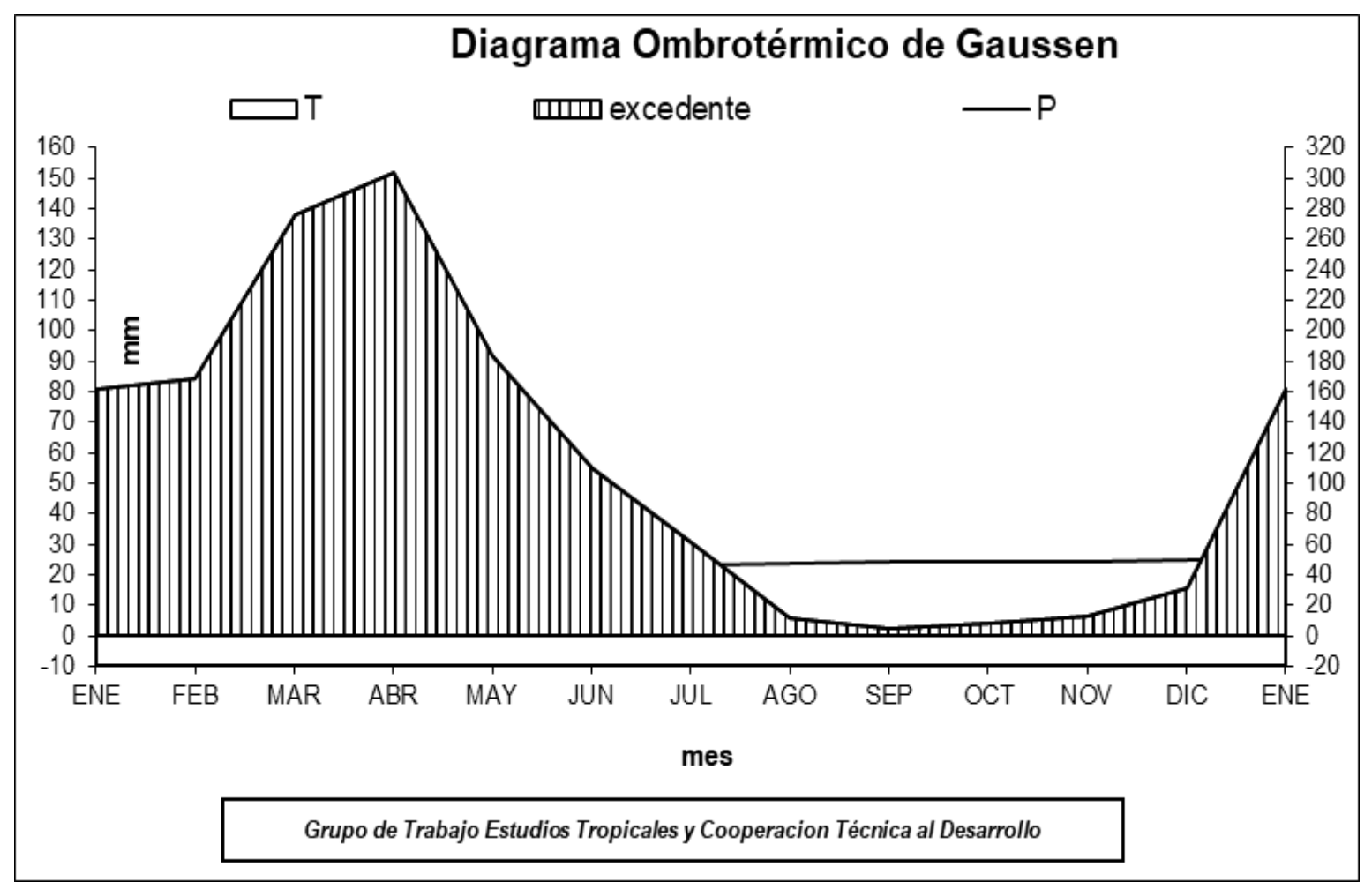

Fonte: Acervo particular dos autores (setembro de 2018)

Figura 10 - Balanço hídrico climatológico do posto de Guaramiranga-CE.

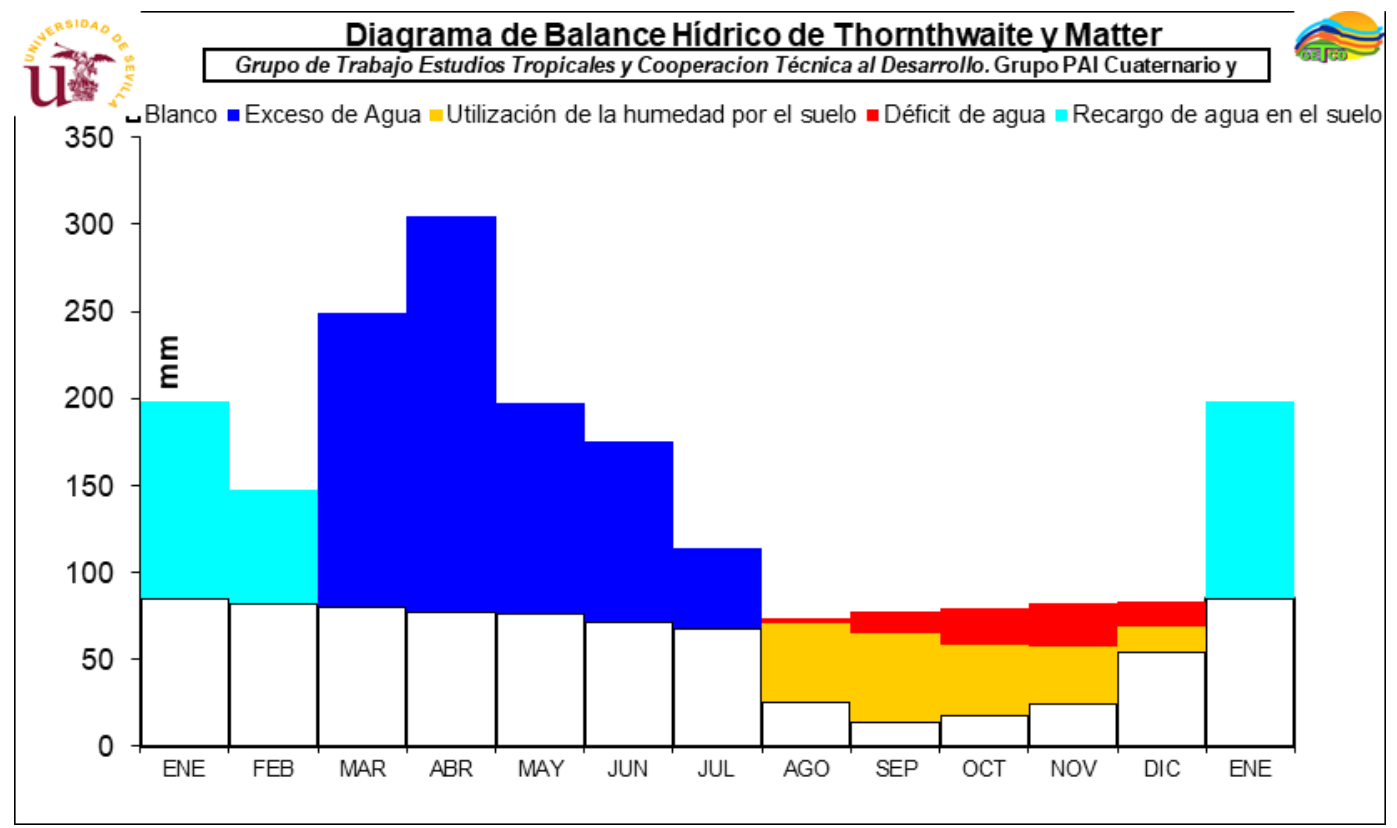

Fonte: Acervo particular dos autores (setembro de 2018) 
Figura 11 - Diagrama ombrotérmico para o posto de Guaramiranga-CE

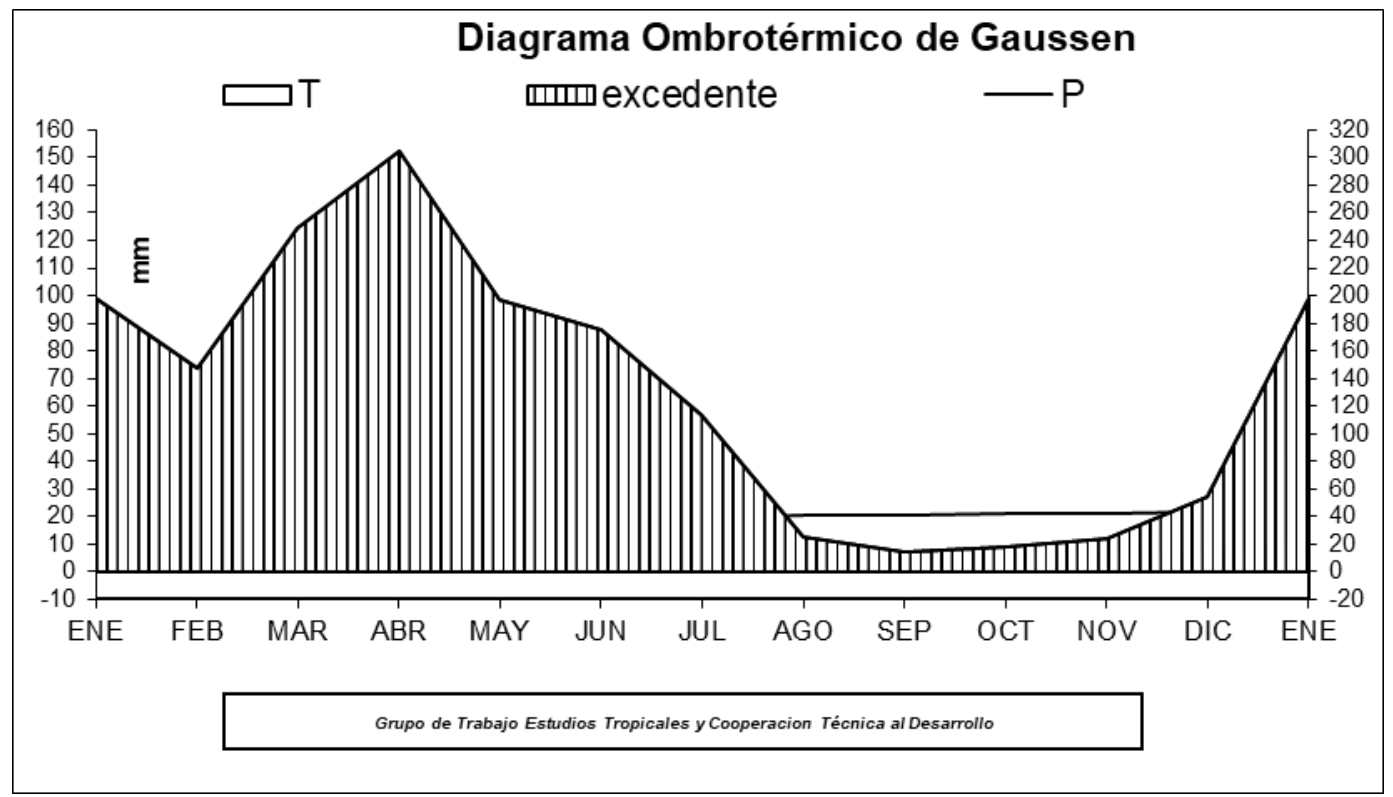

Fonte: Acervo particular dos autores (setembro de 2018)

Para o posto de Acarape-CE que está no sopé da Serra de Baturité, na porção a barlavento, observa-se um período superavitário de dois meses no qual em um mês ocorre reposição da umidade do solo perdida durante o período de seca. Isso ocorre durante os meses de março e abril, onde a ZCIT está em sua posição mais ao sul e provoca as maiores chuvas. O posto apresentou também um período de seca de 6 meses com ápice nos meses de setembro, outubro e novembro.

Para o posto de Caridade-CE, localizado no sopé da serra de Baturité em sua porção a sotavento, observa-se um período superavitário de 2 meses, sendo que mesmo nesses momentos, não há excesso de água no solo, e toda chuva serve para recarregar a umidade perdida durante o período de seca. O diagrama ombrotérmico mostrou um período de seca maior que o observado nas áreas classificadas, como de clima subúmido seco, a exemplo de Acarape. Para esse posto o período de seca ocorre já na metade do mês de maio até o mês de dezembro, tendo seu ápice nos meses de setembro a novembro, onde a ZCIT está mais afastada do Hemisfério Sul.

Para o posto de Palmácia-CE, que está a cerca de $400 \mathrm{~m}$ de altitude, já sob a serra de Baturité, observou-se um período superavitário de seis meses, sendo que em dois ocorre recarga da umidade do solo e em quatro ocorre excesso de água. 0 diagrama ombrotérmico mostrou um período de seca de 5 meses, quando a partir do mês de junho a temperatura média observada é 2 vezes maior que a precipitação. 
Observa-se, também, um aumento do superávit e diminuição do período de seca em relação aos demais tipos climáticos.

Para o posto de Guaramiranga-CE, que está na zona de cimeira do alto relevo com cotas altimétricas que ultrapassam os $800 \mathrm{~m}$, observa-se um período superavitário de sete meses, sendo que em dois deles ocorre recarga da umidade perdida durante o ano e nos demais há excesso de água no solo. O período de seca fica reduzido a pouco mais de três meses e corresponde ao tipo climático mais úmido na região. Aqui se observa o ápice da influência do relevo na definição climática.

\section{CONCLUSÃO}

A serra de Baturité é fundamental na definição climática das porções que estão sob ela e em seu entorno. Isso fica evidente quando se observa a espacialização dos dados referentes aos valores pluviométricos, bem como a distribuição dos tipos climáticos. Esse contexto climático tem influência direta no quadro natural e socioeconômico.

Quanto à metodologia de classificação climática utilizada no trabalho ela se mostrou útil para apresentar a variação dos tipos climáticos, desde o úmido ao semiárido passando pelos subúmidos que figuram como sendo uma transição entre os dois primeiros. Isso não seria possível utilizando sistemas como o de Köppen que não contém a categoria subúmida.

\section{REFERÊNCIAS}

AB'SÁBER, A. O Nordeste brasileiro e a teoria dos refúgios. In: SEMINÁRIO DE TROPICOLOGIA, 2002, Recife. Anais. Recife, Trópico e Meio Ambiente, 2002, p. 35-61.

CAMARA, R. República Dominicana: dinámica del medio físico en la región Caribe (Geografía física, Sabanas y Litoral). Aportación al conocimiento de la tropicalidad insular. 1997. Tese (Doutorado em Geografia) - Programa de Doctorado en Geografía Física. Departamento de Geografía Física y Análisis Geográfico Regional. Universidad de Sevilla, Espanha.

COSTA, Gessivaldo. CELINA - Estimativa de Temperaturas Para o Estado do Ceará. Versão 1.0. UFC, 2007.

FERNANDES, Afrânio. Fitogeografia brasileira: províncias florísticas. Realce editora e indústria gráfica: Fortaleza, 2006. 
FERREIRA, A. G; MELLO, N. G. S. Principais sistemas atmosféricos atuantes sobre a região Nordeste do Brasil e a influência dos oceanos Pacífico e Atlântico no clima da região. Revista Brasileira de Climatologia, v. 1, n. 1, p. 15-28, dezembro. 2005. Disponível em: https://revistas.ufpr.br/revistaabclima/article/download/25215/16909. Acesso em: 10 jan. 2016.

FUNCEME. Calendário das Chuvas no Estado do Ceará. Disponível em: http://www.funceme.br/index.php/areas/23-monitoramento/meteorol\%C3\%B3gico/406chuvas-di\%C3\%A1rias\#site. Acesso em: 11 jan. 2017.

Instituto Brasileiro de Geografia e Estatística. Manual Técnico da Vegetação Brasileira. 2. ed. Rio de Janeiro: IBGE, 2012. Disponível em: https://biblioteca.ibge.gov.br/visualizacao/livros/liv63011.pdf. Acesso em: 16 fev. 2016.

MEIRELES, A. J. de A. As unidades morfo-estruturais do Ceará. in: SILVA, J. B. S [et al] (Orgs). Ceará: um novo olhar geográfico. 2. ed. Fortaleza: Edições Demócrito Rocha, 2007.

MENDONÇA, F.; DANNI-OLIVEIRA, I. M. Climatologia: noções básicas e climas do Brasil. São Paulo: Oficina de Texto, 2007.

MIRANDA, R. A. C de. SANTOS, A. S dos. Balanço hídrico e classificação climática de Thornthwaite em Duas Barras (RJ). GeoUERJ. Ano 10, vol 1, n. 18, p. 171-182, jan/jun. $2008 . \quad$ Disponível em: http://www.epublicacoes.uerj.br/index.php/geouerj/article/view/1384. Acesso em: 20 jul. 2018.

NIMER, E. Climatologia do Brasil. 2. ed. Rio de Janeiro: Fundação IBGE, 1989.

PEREIRA, R. C. M; SILVA, E. V. da. Solos e vegetação do Ceará: características gerais. In SILVA, J. B da; CAVALCANTE, T. C; DANTAS, E. W. C. (Orgs). Ceará: um novo olhar geográfico. 2. ed. Fortaleza: Edições Demócrito Rocha, 2007.

SILVA, Z. R. Climas do Estado do Ceará. Ciên. Agronômica, Fortaleza. Ano 18, Vol 2, p. 89-95, dezembro. 1987. Disponível em: http://www.ccarevista.ufc.br/site/down.php?arq=27rca20.pdf. Acesso em: 18 ago. 2017.

SOUZA, M J N de. Contribuição ao estudo das unidades morfoestruturais do estado do Ceará. Revista de Geologia, ano 1, p. 73-91, junho. 1988.

SOUZA, M. J. N de e OLIVEIRA, V. P. V de. Os Enclaves Úmidos e Subúmidos do Semiárido do Nordeste Brasileiro. Mercator - Revista de Geografia da UFC, Fortaleza, vol $\quad 5, \quad$ n. $\quad 9, \quad 2006 . \quad$ Disponível em: http://www.mercator.ufc.br/index.php/mercator/article/viewArticle/91. Acesso em: 3 ago. 2015.

THORNTHWAITE, C. W.; MATHER, J. R. The water balance. Centerton, NJ: Drexel Institute of Technology - Laboratory of Climatology, 1955. 104p. (Publications in Climatology, vol. VIII, n.1). 
ZANELLA, M. E. As características climáticas e os recursos hídricos do Ceará. In SILVA, J. B. S [et al] (Orgs). Ceará: um novo olhar geográfico. 2. ed. Fortaleza: Edições Demócrito Rocha, 2007. 